\title{
Genetic Characterization and Expression Analysis of Recombinant Manganese Superoxide Dismutase (MnSOD) from Spontaneously Occurring Canine Mammary'Tumor
}

\author{
Richa Arora ${ }^{1}$, Sonal Saxena ${ }^{1 *}$, Sameer Shrivastava ${ }^{1}$, Shahid Hussain ${ }^{1}$, Saumya Srivastava ${ }^{1}$, \\ Resma Kochumanayin Vasu ${ }^{1}$, Priyanka Sharma ${ }^{1}$, Monalisa SahoO ${ }^{2}$, Naveen Kumar ${ }^{3}$
}

\begin{abstract}
${ }^{1}$ Division of Veterinary Biotechnology, ICAR-Indian Veterinary Research Institute, Izatnagar, Bareilly, UP, India; ${ }^{2}$ Division of Veterinary Pathology, ICAR-Indian Veterinary Research Institute, Izatnagar Bareilly, UP, India; ${ }^{3} \mathrm{Di}-$ vision of Veterinary Surgery, ICAR-Indian Veterinary Research Institute, Izatnagar, Bareilly, UP, India.
\end{abstract}

\begin{abstract}
Cancer onset typically encompasses alterations in cellular proliferation, production of reactive oxygen species (ROS), and DNA damage. Manganese superoxide dismutase (MnSOD) is one of the key enzymes for controlling oxidative stress. The role of MnSOD in cancer development is complex. Although initially considered as a tumour suppressor protein, recently it has been looked upon as a potential marker for cancer metastasis. Though MnSOD has been studied extensively in human cancers, not much work has been done for elucidating its role in dog cancers. Further dog MnSOD gene has not been sequenced so far, although dog MnSOD gene sequence predicted using computational biology approaches is present in the GenBank database. Therefore in this study, full-length ORF of sod2 gene, a gene encoding MnSOD enzyme, from a case of canine mixed mammary capillary cystic adenocarcinoma was cloned and sequenced. The sequence showed 100\% similarity with the predicted dog MnSOD sequence present in GenBank database based on computational algorithms. Comparison of deduced amino acid sequence from Canis lupus familiaris and Homo sapiens revealed $92 \%$ similarity, confirming the conserved nature of the protein. Further the full-length MnSOD was expressed in E.coli and purified protein was isolated successfully. The recombinant MnSOD from dog offers a new tool for studying effect of the anti-oxidant enzyme on dog cancer cells, wound healing and other disorders.
\end{abstract}

Keywords $\mid$ MnSOD, Sequence characterization, Dog mammary cancer, Expression

Editor | Kuldeep Dhama, Indian Veterinary Research Institute, Uttar Pradesh, India.

Received | June 20, 2016; Accepted | June 30, 2016; Published | June 06, 2016

*Correspondence | Sonal Saxena, ${ }^{1}$ Division of Veterinary Biotechnology, ICAR-Indian Veterinary Research Institute, Izatnagar, Izatnagar, Bareilly, UP, India;

Email: sonalvet@gmail.com

Citation | Arora R, Saxena S, Shrivastava S, Hussain S, Srivastava S, Vasu RK, Sharma P, Sahoo M, Kumar N (2016). Genetic characterization and expression analysis of recombinant Manganese Superoxide Dismutase (MnSOD) from spontaneously occurring canine mammary tumor. Adv. Anim. Vet. Sci. 4(7): 363-369. DOI | Http://dx.doi.org/10.14737/journal.aavs/2016/4.7.363.369

ISSN (Online) | 2307-8316; ISSN (Print) | 2309-3331

Copyright (C) 2016 Arora et al. This is an open access article distributed under the Creative Commons Attribution License, which permits unrestricted use, distribution, and reproduction in any medium, provided the original work is properly cited.

$\mathrm{C}$ anine mammary cancer is an important neoplastic condition of female dogs (Davidson, 2003; Murphy, 2008; Salas et al., 2015) accounting for more than $40 \%$ of all tumours diagnosed (Sleeckx et al., 2011; Beck et al., 2013). The mortality rates in dogs suffering with canine mammary cancer are atleast three times higher than human breast cancer (Egenvall et al., 2005; Shafiee et al., 2013). In recent years there has been alarming increase in incidence of canine mammary tumor cases due to interaction between genetic and environmental factors (Pharoah et al., 2004; Wang et al., 2012).
Cancer onset typically encompasses alterations in the cellular growth and proliferation, production of reactive oxygen species (ROS), and DNA damage. Reactive oxygen species (ROS) produced endogenously play important role in development of cancers by inducing DNA damage and stimulating cell proliferation which leads to tumour promotion (Clair et al., 1996). Higher levels of ROS contribute to genetic instability, which ultimately results in the stepwise process of carcinogenesis. Further ROS also activate various cancer signalling pathways and transcription factors in tumour cells regulating proliferation, me- 
tastasis and angiogenesis, thus contributing towards cancer progression. A significant role is played by antioxidant enzymes in protecting the cells from oxidative damages. Superoxide dismutases (SODs), glutathione peroxidases and catalases are the main antioxidant enzymes (Fridovich, 1995) present in cell. Superoxide dismutase (SOD) specifically catalyse superoxide radical $\left(\mathrm{O}_{2}-\right)$ conversion to $\mathrm{H}_{2} \mathrm{O}_{2}$ and $\mathrm{O}_{2}$ (Fridovich, 1995). SODs thus protect oxygen-metabolizing cells from the detrimental effects of superoxide free radicals and are therefore considered as key enzymes for controlling oxidative stress (Hassan, 1980). SODs are present in mammalian cells in three isoforms namely SOD1, SOD2 and SOD3. The gene Sod2 encodes manganese superoxide dismutase (MnSOD/SOD2) which requires manganese in the catalytic site of enzyme and whose subcellular location is exclusively mitochondrial matrix (Miao and Clair, 2009). The MnSOD gene is highly conserved in human, bovine, rat and mouse sharing more than 90\% homology in the coding sequence (Meyrick et al., 1994). It has been proved by various transgenic studies that MnSOD protects from cellular apoptosis and injuries induced by oxidative stress (Keller et al., 1988). The role of $\mathrm{MnSOD}$ in cancer development is complex and has been studied for several decades with controversial results. In fact, the exact role of SOD2 and redox state in cancer onset and progression remains poorly understood. While SOD2 downregulation was initially associated with tumor initiation and thus it was proposed as a tumor suppressor gene (Manna et al., 1988; Oberley, 2005) recent studies have reported that SOD2 might favour tumor progression and dissemination (Miar et al., 2015; Termini et al., 2015). Increased SOD2 expression in some cancers like gastric/ esophageal (Izutani et al., 1998), lung (Ho et al., 2001; Svensk et al., 2004), colorectal (Toh et al., 2000), oral (Liu et al., 2010), brain (Haapasalo et al., 2003), cervical (Termini et al., 2011) and skin (Clair et al., 2005) carcinomas have been found to be associated with metastasis and poor disease outcomes. Thus it has been proposed that higher MnSOD levels correlate with the aggressiveness, increased metastatic potential (Malafa et al., 2000) and poor prognosis (Janssen et al., 2000). Therefore, recently it has been looked upon as a potential marker during progression from tumor growth to metastasis. Further autoantibody against $\mathrm{MnSOD}$ have also been reported in various human cancers like hepatocelluar carcinoma (Takashima et al., 2006), lung cancer (Yang et al., 2007), and breast cancer (Hamrita et al., 2008). Autoantibodies against MnSOD have also been reported in dogs with mammary tumours (Zamani-Ahmadmahmudi et al., 2014).

Though MnSOD has been studied extensively in human cancer studies, not much work has been done for studying effect of MnSOD on dog cancers. Only a single study has shown over-expression of MnSOD in dog mammary cancer (Zamani-Ahmadmahmudi et al., 2015). Further dog
MnSOD gene has not been sequenced so far, although dog MnSOD gene sequence predicted using computational biology approaches is reported in the GenBank database. Therefore, this study was undertaken to analyze dog $\mathrm{MnSOD}$ gene sequence from a case of canine mammary cancer. Further in this study recombinant $\mathrm{MnSOD}$ protein was successfully expressed and purified from E.coli. The recombinant protein may prove useful in determining effect of $\mathrm{MnSOD}$ on dog cancer cells and also in development of assays for detecting MnSOD auto-antibodies in cases of dog cancers.

Canine mammary tumour (CMT) tissue used in the study was obtained after surgical removal of tumour from a clinical case of CMT referred for surgery to the "Referral Veterinary Polyclinic, Indian Veterinary Research Institute (IVRI), Izatnagar, Bareilly, India.

Escherichia coli (E.coli) DH5 $\alpha$ cells (Promega, Madison) and $E$. coli BL21 (DE3) cells (Invitrogen, USA) were used in this study for gene cloning experiments and expression of heterologous protein in E. coli respectively.

Total RNA was isolated from tissue sample by RNeasyplus $^{\mathrm{TM}}$ mini kit (Qiagen, Hilden, Germany) as per the manufacturer's instructions. The RNA was quantified using Qubit RNA BR Assay Kit (Invitrogen, USA) and the integrity of RNA was confirmed by Experion RNA StdSens Analysis Kit (Biorad) using "Experion Automated Electrophoresis System" (Bio-Rad, Hercules, USA. The cDNA was then prepared from total RNA using Revert Aid cDNA synthesis kit (Fermentas, USA) as per the manufacturer's instructions. The cDNA from tumour sample was synthesized using Oligo (dT) 18 primers and $2 \mu \mathrm{g}$ total RNA in a volume of $20 \mu \mathrm{L}$. The prepared cDNA was stored at $-80^{\circ} \mathrm{C}$ for further use.

The primers were designed for amplification of full length MnSOD gene coding region using Premier 5.0 software (National Bioscience), analyzed using oligoanalyzer 3.1 and custom synthesized by Integrated DNA technologies (USA). Sites for restriction enzymes $\mathrm{XbaI}$ and ApaI sites were incorporated at the 5 ' ends of forward and reverse primer, respectively. The cDNA from CMT tissue was used as a template for amplification of MnSOD gene. Cycling conditions for amplification of the gene included, initial denaturation at $95^{\circ} \mathrm{C}$ for $5 \mathrm{~min}$, followed by 35 cycles of denaturation at $98^{\circ} \mathrm{C}$ for $20 \mathrm{sec}$,annealing at $60^{\circ} \mathrm{C}$ for 15 sec and extension at $72^{\circ} \mathrm{C}$ for $15 \mathrm{sec}$ with final extension at $72^{\circ} \mathrm{C}$ for $10 \mathrm{~min}$. The PCR was performed in a $50 \mu \mathrm{L}$ reaction mixture containing $25 \mu \mathrm{L}$ KAPA hi-fidelityPCR master mix $(2 \mathrm{X}), 0.5 \mu \mathrm{L}$ of $20 \mathrm{pM}$ each of forward and reverse primer and $3 \mu \mathrm{L}$ of template cDNA. As per manufacturer's instructions, the amplified PCR product was purified using min-elute ${ }^{\circledR}$ PCR purification kit (Qiagen, Hilden, 
Germany). R.E. digestion of PCR product was done using $\mathrm{XbaI}$ and ApaI restriction endonucleases (NEB, England) at $37^{\circ} \mathrm{C}$ for $2 \mathrm{~h}$. The pH6HTN His 6 HaloTag ${ }^{\circledR}$ T7 Vector (Promega, Madison) was also subjected to RE digestion with $\mathrm{XbaI}$ and ApaI to generate complementary overhangs. $\mathrm{PCR}$ product and digested vector were then subjected to overnight ligation at $4^{\circ} \mathrm{C}$ using T4 DNA ligase (Promega, Madison, USA). Ligated product was subsequently transformed into $E$. coli $\mathrm{DH} 5 \alpha$ competent cells. The recombinant clones were screened by colony PCR. The recombinant plasmid was purified from the overnight grown culture using PureYield ${ }^{\mathrm{TM}}$ plasmid miniprep system (Promega) and subjected to RE digestion using $\mathrm{XbaI}$ and ApaI restriction endonucleases for further confirmation of the recombinant clone. Recombinant plasmid isolated from overnight grown culture was then sent for plasmid DNA sequencing at Eurofins Genomics India Pvt Ltd (Bangalore, India). Analysis of gene sequence was done using DNA-STAR sequence analysis software and basic local alignment search (BLAST) tool.

The recombinant plasmid was transformed in BL-21 E.coli competent cells for expression of MnSOD gene. Colonies produced on plates were revived overnight and inoculated in $100 \mathrm{ml}$ culture containing $100 \mathrm{ug} / \mathrm{ml}$ ampicillin for large-scale expression and purification of recombinant protein. The conditions like IPTG concentration, induction temperature and time etc. were optimized for expression of recombinant protein. Optimum expression of MnSOD protein was observed when the inoculum was induced for 6 hrs with isopropy- $\beta$-D-thiogalactopyranoside (IPTG) at a final concentration of $1 \mathrm{mM}$ when the $\mathrm{OD}_{600} \mathrm{nM}$ reached 0.4-0.8. After induction, the culture pellet was solubilized with $8 \mathrm{M}$ urea and induced, as well as un-induced, lysates were analyzed using $12 \%$ sodium dodecyl sulfate-polyacrylamide gel electrophoresis (SDS-PAGE) along with protein molecular weight marker. Once the expression was confirmed, recombinant protein was purified by affinity chromatography using AKTA pure 25M Fast Performance Liquid Chromatography (FPLC) (GE healthcare, Sweden). The culture pellet was solubilized with $8 \mathrm{M}$ urea and lysate was loaded on HisTrap FF affinity column. The impurities were then washed in buffer with $100 \mathrm{mM}$ $\mathrm{NaH}_{2} \mathrm{PO}_{4}, 10 \mathrm{mM}$ tris- $\mathrm{Cl}$ and $8 \mathrm{M}$ urea $(\mathrm{pH}$ 6.3) and finally eluted in elution buffer containing $100 \mathrm{mM} \mathrm{NaH}_{2} \mathrm{PO}_{4}$, $10 \mathrm{mM}$ tris- $\mathrm{Cl}$ and $8 \mathrm{M}$ urea $(\mathrm{pH} 4.5)$. The concentration of purified protein was determined by Qubit ${ }^{\mathrm{TM}}$ protein assay kit (Invitrogen, USA) according to the manufacturer's protocol. The purity of the recombinant protein was analyzed by SDS-PAGE. The recombinant protein was dialyzed against $\mathrm{PBS}$ and then stored at $-80^{\circ} \mathrm{C}$ till further use.

The recombinant MnSOD protein was confirmed by western blotting using commercial rabbit polyclonal antibodies against human SOD2 protein (Santa Cruz). Purified Mn-
SOD protein, was run on $12 \%$ SDS-PAGE, transferred to a nitrocellulose membrane and blocked overnight by immersing in 5\% skimmed milk in PBS. After washing once in PBS, the membrane was incubated in 1:100 dilution of rabbit anti-SOD2 antibody (Santa Cruz) as primary antibody for 1 hour at room temperature. The membrane was washed thrice with PBS-T and then incubated with 1:4000 dilution of anti-rabbit $\operatorname{IgG}$ conjugated to Horse-radish peroxidase (Sigma Aldrich). After washing thrice with PBST, the antigen-antibody complexes were developed using diaminobenzidine (DAB) (Sigma-Aldrich).

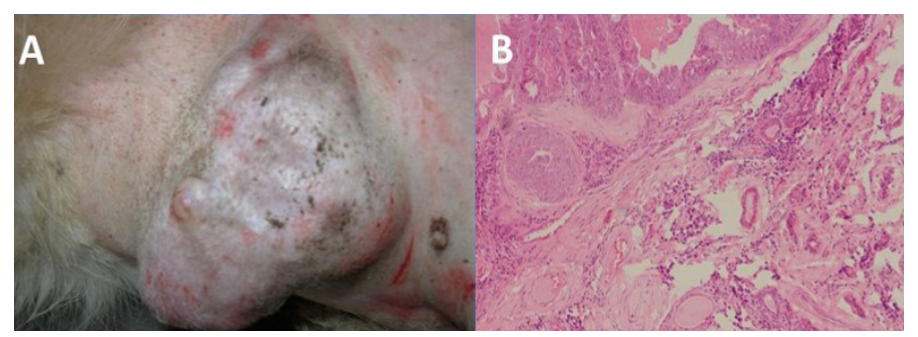

Figure 1: Gross (A) and histopathogical (B) analysis of tumour tissue used for amplification of MnSOD gene. Upon histopathological analysis of $\mathrm{H} \& \mathrm{E}$ stained tissue section, tumour was classified as mixed mammary capillary cystic adenocarcinoma by histopathological examination

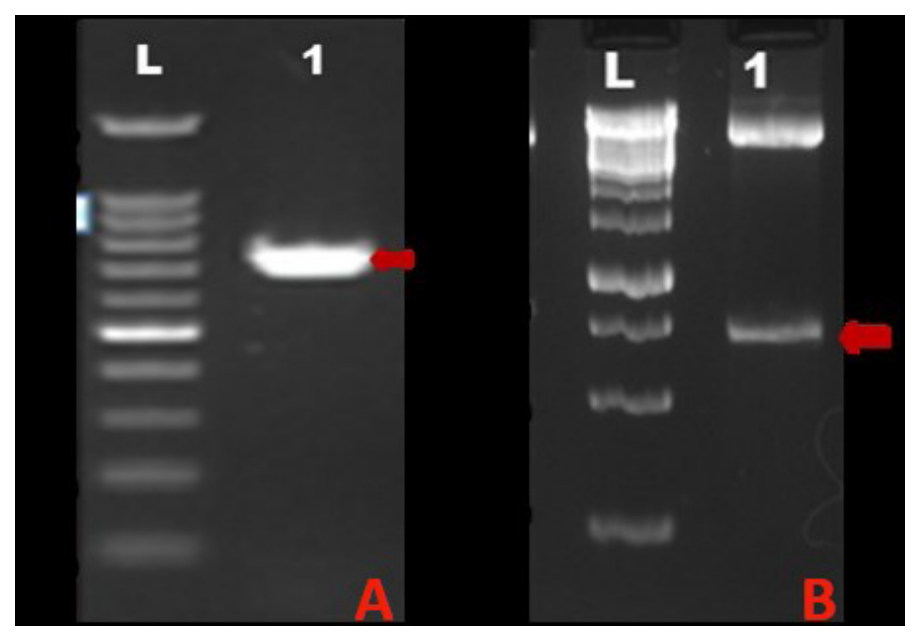

Figure 2: Amplification and cloning of full-length ORF of MnSOD gene

A) Lane L: 100BP DNA ladder, Lane 1: Amplified MnSOD gene PCR product; B) Lane L: $1 \mathrm{~Kb}$ DNA ladder, Lane 1: 713bp insert corresponding to MnSOD gene released upon RE digestion of recombinant plasmid with Xba I and Apa I

The tumour tissue from which coding region of sod2 gene was amplified was classified as mixed mammary capillary cystic adenocarcinoma by histopathological examination of H\&E stained tissue section (Figure 1). The PCR amplification of the MnSOD gene was performed as described earlier. The amplified product showed expected band size of $713 \mathrm{bp}$ on agarose gel electrophoresis (Figure 2A). Upon cloning of amplified product in pH6HTNHis6 HaloTag ${ }^{\circledR}$ T7 Vector (Promega), the colonies showed amplicon size corresponding to MnSOD gene by colony PCR. 
"Canis lupus MnSOD.pro" "Homo sapiens MnSOD.pro

"Canis lupus MnSOD.pro" "Homo sapiens MnSOD.pro

"Canis lupus MnSOD.pro" "Homo sapiens MnSOD.pro

"Canis lupus MnSOD.pro" "Homo sapiens MnSOD.pro

"Canis lupus MnSOD.pro" "Homo sapiens MnSOD.pro

"Canis lupus MnSOD.pro" "Homo sapiens MnSOD.pro

"Canis lupus MnSOD.pro" "Homo sapiens MnSOD.pro
MLSRAALSTSRTLVPALGCLGSRQKHSLPD MLSRAVCGTSRQLAPALGYLGSRQKHSLPD
50

LPYDYGALEPH I NAQ I MQL HíHSKHHAAYVN
LPYDYGALEPH I NAQ I MQL HHS KHAAYVN
NLNT I EEKYLEALEKGDITAQI ALQPGLKF NLNVNEEKYQEALAKGDVTAQ I ALQPALKF

100

110

120

NGGGH I NÍHS I FWTNLSPKGGGEPKGELLEA NGGGH I NHIS I FWT NLSPNGGGEPKGELLEA

130

140

150

I KRDFGSFDKFKEKLTTVSVGVQGSGWGWL I KRDFGSFDKFKEKLTAASVGVQGSGWGWL

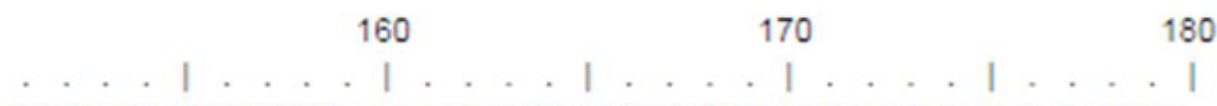

GFNKEQGRLQ I A A C F N D P LQGTTGL I PLL GFNKERGHLQIAACPNQDPLQGTTGLIPLL

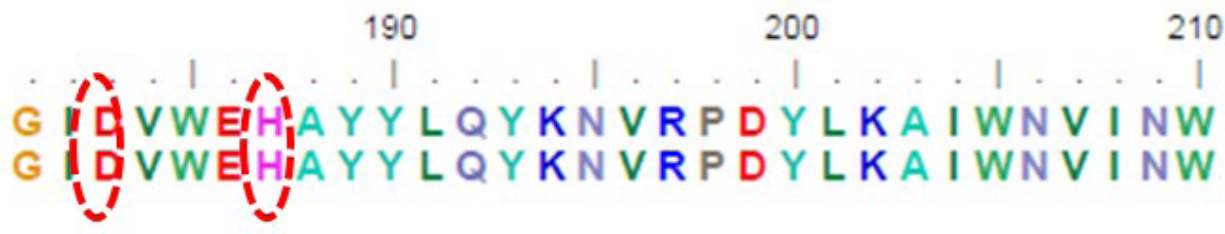

220

"Canis lupus MnSOD.pro"

E N V T E R Y M A C K K "Homo sapiens MnSOD.pro E N V T E R Y M A C K K

Figure 3: Deduced amino acid sequences of mitochondrial manganese superoxide dismutase from Canis lupus familiaris and Homo sapiens (Accession no: CAA42066.1); The amino acids highlighted by red circles indicate four putative manganese binding sites conserved among all eukaryotes

When the plasmid isolated from recombinant colony was subjected to $\mathrm{RE}$ digestion using $\mathrm{XbaI}$ and $\mathrm{ApaI}$ restriction endonucleases, insert of size corresponding to $\mathrm{Mn}$ SOD gene (713 bp) was released from the vector. Figure $2 \mathrm{~B}$ shows $\mathrm{RE}$ analysis of the recombinant plasmid. The recombinant plasmid was further confirmed by plasmid DNA sequencing. Upon sequence analysis, it was observed that the sequence of $\mathrm{MnSOD}$ gene from a case of mixed mammary capillary cystic adenocarcinoma was $100 \%$ similar to the predicted MnSOD gene sequence already present in the Genbank database, predicted by computational biology approaches. Comparison of the deduced amino acid sequences from dog protein with human MnSOD revealed $92 \%$ similarity between the two (Figure 3). Four putative manganese binding sites, conserved among all eukaryotes, were also found to be present in recombinant dog MnSOD (highlighted by red circles in Figure 3).

The recombinant plasmid $\mathrm{pH} 6 \mathrm{HTN}-\mathrm{MnSOD}$ was transformed in E.coli BL21 DE3 cells. Optimum expression of MnSOD was observed upon induction of recombinant plasmid transformed cells for $6 \mathrm{hrs}$ with $1 \mathrm{mM}$ IPTG, when the $\mathrm{OD}_{600} \mathrm{nM}$ reached 0.4-0.8. Upon SDS PAGE analysis of induced as well as uninduced lysates, $62 \mathrm{kda}$ band corre- 
sponding to the size of recombinant MnSOD protein was observed as shown in Figure 4A. The recombinant protein was purified by Histrap FF column (GE Healthcare) and eluted protein showed single band of $62 \mathrm{kDa}$ molecular weight on SDS-PAGE analysis (Figure 4B). The purity of the protein was reconfirmed by Experion automated protein electrophoresis system and the recombinant protein was found to be approximately $95 \%$ pure. The yield of the purified protein, as measured by Qubit ${ }^{\mathrm{TM}}$ protein assay kit (Invitrogen, USA), was approximately $2 \mathrm{mg} / 100 \mathrm{ml}$ of bacterial culture.

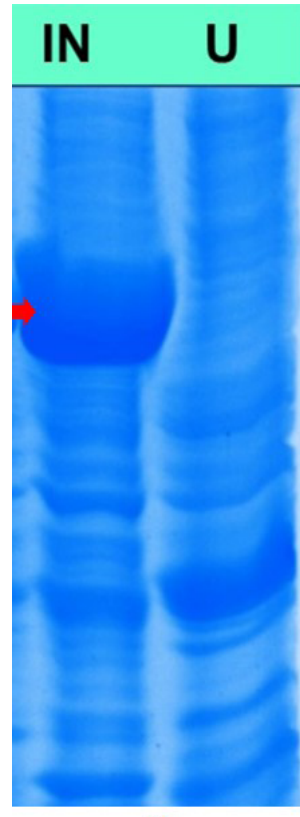

A

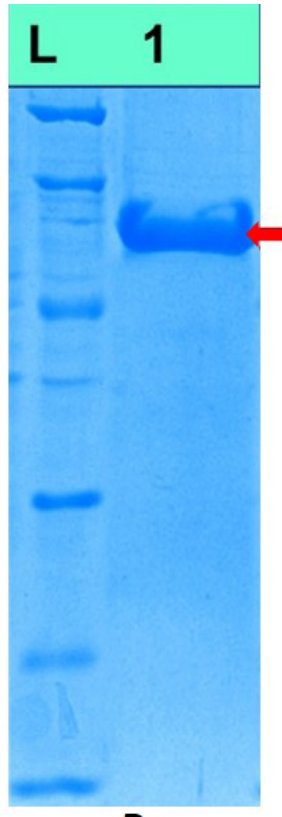

B

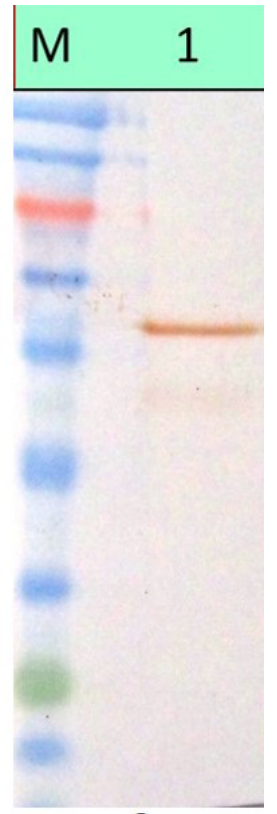

C
Figure 4: Expression, purification and characterization of recombinant $\mathrm{MnSOD}$ protein

A) SDS PAGE analysis of induced and uninduced bacterial lysates, Lane IN: Lysate from recombinant cultures induced with $1 \mathrm{mM}$ IPTG, Lane U: Lysate from uninduced bacterial cultures; B) SDS PAGE analysis of purified MnSOD protein. Lane L: Unstained low range protein molecular weight marker, Lane 1: Purified recombinant MnSOD protein; C) Western blotanalysis of recombinant MnSOD protein, Lane M: Colour plus prestained protein molecular weight marker, Lane 1: recombinant MnSOD protein showing immunoreactivity with commercial polyclonal antibodies against human SOD2 protein

Purified dog recombinant MnSOD was run on $12 \%$ SDSPAGE \& transferred to a nitrocellulose membrane. Upon immunoblot analysis, band corresponding to the size of recombinant dog MnSOD was observed which shows immunoreactivity of the dog protein with commercial polyclonal antibody against human SOD2 protein. This confirms the cross-reactivity of human antibodies with dog protein owing to amino-acid similarity between human and dog MnSOD. Figure 4C shows western blot analysis of recombinant $\mathrm{MnSOD}$ protein.

Inspite of initial response to conventional chemothera- pies, a number of patients die due to metastasis, suggesting that new modalities are required for treatment of cancers. Generation of ROS not only causes oxidative injuries, but also act by providing signaling molecules for regulating cell proliferation and downstream gene expression. Induction of $\mathrm{MnSOD}$ is attaining attention as an effective novel mechanism of cancer chemoprevention because overexpression of this enzyme suppresses tumor formation and has ability to modulate multiple pathways contributing towards carcinogenesis. Studies in human have shown that recombinant MnSOD (rMnSOD) may be exploited for the treatment of chronoaging, photoaging etc, apart from modulation of cancers. The rMnSOD has selective antitumor effect on cancer cells due to the low catalase activity present in most tumor cells than in normal cells. The hydrogen peroxide $\left(\mathrm{H}_{2} \mathrm{O}_{2}\right)$ enzymatically produced inside the cell from free radicals and ROS by the $\mathrm{rMnSOD}$ may thus specifically damage tumor cells (Mancini et al., 2008). Further studies have also shown that rMnSOD has selective radio sensitizing effect on tumour cells (Borelli et al., 2009). Recently, MnSOD and anti-MnSOD autoantibodies are being explored as a potential marker during progression from tumor growth to metastasis.

This study allowed the characterization of full-length ORF of sod2 gene, a gene encoding MnSOD enzyme, from a case of canine mixed mammary capillary cystic adenocarcinoma. The complete nucleotide sequences of sod2 gene of $\mathrm{dog}$ have been previously characterized by in silico computational biology approaches, however this is the first report on characterization of $\mathrm{MnSOD}$ gene sequence from dog tissue. Comparison of deduced amino acid sequence from Canis lupus familiaris and Homo sapiens revealed 92\% similarity, confirming the conserved nature of the protein. Further the protein was expressed in E.coli and purified protein was isolated successfully. The recombinant $\mathrm{Mn}$ SOD from dog offers interesting, new perspectives for studying effect of the anti-oxidant enzyme on cancer cells, wound healing and other disorders.

\section{ACKNOWLEDGEMENTS}

The authors are thankful to Director, IVRI, and Izatnagar for providing necessary infrastructure and facilities to carry out this research work. Authors are also thankful to Department of Biotechnology (DBT), Govt. of India (Project grant No. BT/PR13900/ADV/57/44/2010) and Indian Council of Agricultural Research (ICAR) NAE programme on biosensors for supporting the study by research grants.

\section{CONFLICT OF INTEREST}

Authors of this manuscript declare no conflict of interest. 


\section{AUTHORS'CONTRIBUTION}

R. Arora conducted the experiments. S. Saxena \& S. Shrivastava designed the work, helped in conducting the experiments and drafted the manuscript. S. Hussain, R.K. Vasu helped in optimization of MnSOD protein expression. S. Srivastava \& P. Sharma helped in data analysis. M. Sahoo helped in histopathological analysis. N. Kumar collected tumour tissues from surgically operated CMT cases.

\section{REFERENCES}

-Beck J, Hennecke S, Bornemann-Kolatzki K, Urnovitz, HB and Neumann S (2013). Genome aberrations in canine mammary carcinomas and their detection in cell-free plasma DNA. PLoS One. 8(9): e75485. http://dx.doi.org/10.1371/ journal.pone.0075485

-Borrelli A, Schiattarella A, Mancini R, Morrica B, Cerciello V, Mormile M, D'Alesio V, Bottalico L, Morelli F, D'Armiento FP, Mancini A 1 (2009). A recombinant MnSOD is radio protective for normal cells and radio sensitizing for tumor cells. Free Radical Biol. Med. 46(1): 110-116. http://dx.doi. org/10.1016/j.freeradbiomed.2008.10.030

- Clair D, Zhao Y, Chaiswing L, Oberley T (2005). Modulation of skin tumorigenesis by SOD. Biomed. Pharmacother. 59(4): 209-241. http://dx.doi.org/10.1016/j.biopha.2005.03.004

- Clair DK (1996). Tumor suppression by manganese superoxide dismutase: a novel function of MnSOD? Oncol. Rep. 3: 429-433.

-Davidson EB (2003). Treatment of mammary tumors in dogs and cats. Proceedings of the North American Veterinary Conference. 66: 1036-1038.

- Egenvall A, Bonnett BN, Ohagen P, Olson P,Hedhammar A, and Euler HV (2005). Incidence of and survival after mammary tumors in a population of over 80,000 insured female dogs in Sweden from 1995 to 2002. Prev. Vet. Med. 69: 109-127. http://dx.doi.org/10.1016/j.prevetmed.2005.01.014

- Fridovich I (1995). Superoxide radical and superoxide dismutases. Annu. Rev. Biochem. 64: 97-112. http://dx.doi. org/10.1146/annurev.bi.64.070195.000525

-Haapasalo H, Kyläniemi M, Paunul N, Kinnula VL, Soini Y (2003). Expression of antioxidant enzymes in astrocytic brain tumors. Brain Pathol. 13(2): 155-64. http://dx.doi. org/10.1111/j.1750-3639.2003.tb00015.x

-Hamrita B, Chahed K, Kabbage M, Guillier C, Trimeche L, Cha"1eb M, Chouchane A (2008). Identification of tumor antigens that elicit a humoral immune response in breast cancer patients' sera by serological proteome analysis (SERPA). Clin. Chim. Acta. 393: 95-102. http://dx.doi. org/10.1016/j.cca.2008.03.017

-Hassan HM (1980). Superoxide dismutases. Ciba Found Symp. 79: 125-142. http://dx.doi.org/10.1002/9780470720622. ch7

-Ho JC-M, Zheng S, Comhair SA, Farver C, Erzurum SC (2001). Differential expression of manganese superoxide dismutase and catalase in lung cancer. Cancer Res. 61(23): 8578-8577.

-Janssen AM, Bosman CB, Van Duijn W, Oostendorp-van de Ruit MM, Kubben FJ, Griffioen G (2000). Superoxide dismutases in gastric and esophageal cancer and the 3183-9211.

-Keller JN, Kindy MS, Holtsberg FW, St Clair DK, Yen HC, Germeyer A, Steiner S M, Bruce-Keller AJ, Hutchins JB and Mattson MP (1998). Mitochondrial manganese superoxide dismutase prevents neural apoptosis and reduces ischemic brain injury: suppression of peroxynitrite production, lipid peroxidation, and mitochondrial dysfunction. J. Neurosci. 18: 687-697.

- Oberley LW (2005). Mechanism of the tumor suppressive effect of MnSOD overexpression. Biomed. Pharmacother. 59(4): 143-148. http://dx.doi.org/10.1016/j.biopha.2005.03.006

-Liu X, Wang A, Lo Muzio L, Kolokythas A, Sheng S, Rubini C (2010). Deregulation of manganese superoxide dismutase (SOD2) expression and lymph node metastasis in tongue squamous cell carcinoma. BMC Cancer. 10: 365. http:// dx.doi.org/10.1186/1471-2407-10-365

-Malafa M, Margenthaler J, Webb B, Neitzel L, and Christophersen M (2000). MnSOD expression is increased in metastatic gastric cancer. J. Surg. Res. 88 (2): 130-134. http://dx.doi.org/10.1006/jsre.1999.5773

-Mancini A, Borrelli A, Schiattarella A, Aloj L, Aurilio M, Morelli F, Pica A, Occhiello A, Lorizio R, Mancini R, Sica A, Mazzarella L, Sica F,Grieco P, Novellino E, Pagnozzi D, Pucci P, Rommelaere J (2008). Biophysicaland biochemical characterization of a liposarcoma-derivedrecombinant $\mathrm{MnSOD}$ protein acting as an anticancer agent. Int. J. Cancer. 123(11): 2684-2695. http://dx.doi.org/10.1002/ijc.23791

-Manna SK, Zhang HJ, Yan T, Oberley LW and Aggarwal BB (1998). Overexpression of manganese superoxide dismutase suppresses tumor necrosis factor-induced apoptosis and activation of nuclear transcription factor $-\kappa \mathrm{B}$ and activated protein-1. J. Biol. Chem. 273: 13245-13254. http://dx.doi. org/10.1074/jbc.273.21.13245

-Meyrick B, Magnuson MA (1994). Identification and functional characterization of the bovine manganous superoxide dismutase promoter. Am. J. Respirat. Cell Mol. Biol. 10(1): 113-121. http://dx.doi.org/10.1165/ajrcmb.10.1.8292376

- Miao L, St Clair DK (2009). Regulation of superoxide dismutase genes: Implications in disease. Free Radic. Biol. Med. 47: 344-356. http://dx.doi.org/10.1016/j. freeradbiomed.2009.05.018

- Miar A, Hevia D, Muñoz-Cimadevilla H, Astudillo A, Velasco J, Sainz RM, Mayo JC (2015). Manganese superoxide dismutase (SOD2/MnSOD) / catalase and SOD2/GPx1 ratios as biomarkers for tumor progression and metastasis in prostate, colon, and lung cancer.Free Radic. Biol.Med. 85: 4555. http://dx.doi.org/10.1016/j.freeradbiomed.2015.04.001

-Murphy S (2008). Mammary tumours in dogs and cats. Practice. 30: 334-339. http://dx.doi.org/10.1136/inpract.30.6.334

-Pharoah PDP, Dunning AM, Ponder BAJ and Easton DF (2004). Association studies for finding cancer-susceptibility genetic variants. Nat. Rev. Cancer. 4: 850-860. http://dx.doi. org/10.1038/nrc1476

-Izutani R, Asano M, Imano D, Kuroda M, Kato, and Ohyanagi $H$ (1998). Expression of manganese superoxide $S$ dismutase in esophageal and gastric cancers. J. Gastroenterol. 33(6): 816-822. http://dx.doi.org/10.1007/s005350050181

-Salas Y, Marquez A, Diaz D and Romero L (2015). Epidemiological study of mammary tumors in female dogs diagnosed during the period 2002-2012: A growing animal health problem. PloS One. 10(5): e012738110. http:// 
- Shafiee R, Javanbakht J, Atyabi N, Kheradmand P, Kheradmand D, Bahrami A, Khadivar F (2013). Diagnosis, classification and grading of canine mammary tumours as a model to study human breast cancer: Anclinico-cytohistopathological study with environmental factors influencing public health and medicine. Cancer Cell Int. 13: 79. http://dx.doi. org/10.1186/1475-2867-13-79

-Sleeckx N, Rooster H de, Kroeze EJBV, GinnekenC van and BrantegemL van (2011). Canine mammary tumours, an overview. Reprod. Domest. Anim. 46: 1112-1131. http:// dx.doi.org/10.1111/j.1439-0531.2011.01816.x

-Svensk AM, Soini Y, Pääkkö P, Hiravikoski P, Kinnula VL (2004). Differential expression of superoxide dismutases in lung cancer. Am. J. Clin. Pathol. 122(3): 395-404. http:// dx.doi.org/10.1309/A45QHB0QRRX6CT9A

-Takashima M, Kuramitsu Y, Yokoyama Y, Lizuka N, Harada T, Fujimoto M, Sakaida I, Okita K, Oka M, Nakamura K (2006). Proteomic analysis of autoantibodies in patients with hepatocellular carcinoma. Proteomics. 6: 3894-3900. http://dx.doi.org/10.1002/pmic.200500346

-Termini L, Filho AL, Maciag PC, Etlinger D, Alves VA, Nonogaki S (2011). Deregulated expression of superoxide dismutase-2 correlates with different stages of cervical neoplasia. Dis. Markers. 30(6): 275-811. http://dx.doi.
-Termini L, Fregnani JH, BoccardoE (2015). SOD2 immunoexpression predicts lymph node metastasis in penile cancer. BMC Clinic. Pathol. 15: 31- 42. http:// dx.doi.org/10.1186/s12907-015-0003-7

-Toh Y, Kuninaka S, Oshiro T, Ikeda Y, Nakashima H, Baba H (2000). Overexpression of manganese superoxide dismutase mRNA may correlate with aggressiveness in gastric and colorectal adenocarcinomas. Int. J. Oncol. 17(1): 107-121. http://dx.doi.org/10.3892/ijo.17.1.107

-Wang X, Huang L,Xu Y, Shi Z, and Wang Y (2012). Association between survivin $-31 \mathrm{G}>\mathrm{C}$ promoter polymorphism and cancer risk: A meta-analysis. Eur. J. Hum. Genet. 20: 790795. http://dx.doi.org/10.1038/ejhg.2011.276

-Yang F, Xiao ZQ, Zhang XZ, Li C, Zhang PF, Li MY, Chen Y, Zhu GQ, Sun Y, Liu YF, Chen ZC (2007). Identification of tumor antigens in human lung squamous carcinoma by serological proteome analysis. J. Proteome. Res. 6(2): 751850. http://dx.doi.org/10.1021/pr0602287

-Zamani-Ahmadmahmudi M, Nassiri SM, Rahbarghazi R (2014). Serological proteome analysis of dogs with breast cancer unveils common serum biomarkers with human counterparts. Electrophoresis. 35(6): 101-901. http:// dx.doi.org/10.1002/elps.201300461 